http://www.pakjas.com.pk

\title{
Morpho-phenological characterization of grape (Vitis vinifera L.) germplasm grown in northern zones of Punjab, Pakistan
}

\author{
Muhammad Tahir Akram ${ }^{1, *}$, Rashad Qadri², Muhammad Azam Khan ${ }^{1}$, Ishfaq Ahmad Hafiz ${ }^{1}$, Numrah \\ Nisar ${ }^{3}$, M. M. Khan ${ }^{4}$, Muhammad Aqeel Feroze ${ }^{5}$ and Khalid Hussain ${ }^{2}$ \\ ${ }^{1}$ Department of Horticulture, PMAS-Arid Agriculture University, Rawalpindi, Pakistan; ${ }^{2}$ Institute of Horticultural Sciences, \\ University of Agriculture Faisalabad, Pakistan; ${ }^{3}$ Environmental Science Department, Lahore College for Women University, \\ Lahore, Pakistan; ${ }^{4}$ Department of Plant Sciences, College of Agricultural and Marine Sciences, Sultan Qaboos University, \\ P.O. Box 34, Al-Khod 123, Muscat, Sultanate of Oman; ${ }^{5}$ Barani Agriculture Research Institute, Chakwal, Pakistan. \\ *Corresponding author’s e-mail: tahiruaf786@gmail.com
}

\begin{abstract}
This endeavor includes thirty grapes' genotypes grown in northern zones of Punjab, Pakistan to determine similarities and dissimilarities in forty-four morphological traits according to the descriptor "International Plant Genetic Resources Institute (IPGRI)". The relation between the genotypes was determined by principal component analysis (PCA), and similarity was worked out by using cluster analysis. The dendrogram divided the genotypes into two main groups with classes and subclasses. The variation present within the class was up to $81.72 \%$ while the difference between classes was $18.28 \%$. The morphological quantitative traits such as bunch length, bunch width, bunch weight, peduncle length, the weight of 10 berries, number of berry in a bunch, berry length, and berry width were in the following range $27.50-11 \mathrm{~cm}, 13.75-5 \mathrm{~cm}, 583.56-77.70 \mathrm{~g}, 6.50-1.55 \mathrm{~cm}$, 53.70-9.70 g, 354-28, 27.37-11.40 $\mathrm{mm}$ and 18.06-10.41 mm respectively, which indicated a wide level of diversity in the selected genotypes. Based on phenological attributes, "Regina", "Perlet", and "Early White" were found early maturing genotypes to prevent berry rotting due to monsoon rains at the final stage of ripening. The data generated in this study would be helpful to preserve the existing germplasm and be available for designing future breeding programs.
\end{abstract}

Keywords: Cluster analysis; grapevines; IPGRI; morphology; principal component analysis.

\section{INTRODUCTION}

Grape (Vitis vinifera L.) is an important horticultural species that is cultivated worldwide for wine and table purposes. It is one of the most remunerative fruit crops of Pakistan, mainly grown for table purposes. Table grape is known as "European grape" that are emerged between Black and Caspian area (Uddin et al., 2011). Grapes are included among rare fruits of the world which are cultivated from tropical to temperate zones of the world due to their huge diversification. It is believed that genus Vitis contains above than 100 species, out of 44 are considered ambiguous due to interspecific hybrids (Sajid et al., 2006). Grapes are a good source of several minerals, vitamins, antioxidants and phenolic compounds required for human health (De Lorenzis et al., 2015). These compounds have anti-inflammatory, anti-aging and antimicrobial properties which protect from cardiovascular diseases (Mattivi et al., 2009; Lorrain et al., 2011).
In Pakistan, the northern areas of Punjab, Baluchistan and KPK have great grapes diversity and it is cultivated on an area of 15 thousand hectares with 643 thousand tons' production (GOP 2013). However, these areas require characterization for good production (Sajid and Ahmed 2008). In Punjab province, the Potohar area is becoming famous for the commercial production of grapes' early mature genotypes due to suitable climate conditions of the region. In grapes, early mature cultivars are generally preferred for low altitude regions while late-maturing cultivars are grown at high altitudes (Sabir et al., 2009). The climate of a particular place greatly affects the grapes' diversity and production of the crop (Akram et al., 2019).

Globally, the knowledge of grape genetic resources has enormously increased the interests of scientists and researchers as germplasm is a valuable source for species conservation, understanding gene functions and development of new and improved lines (Khadivi et al., 2019; Ates et al., 2011; Khawale and Singh 2005). In grapes, ampelography is

Akram, M.T., R. Qadri, M.A. Khan, I.A. Hafiz, N. Nisar, M.M. Khan, M.A. Feroze and K. Hussain. 2021. Morpho-phenological characterization of grape (Vitis vinifera L.) germplasm grown in northern zones of Punjab, Pakistan. Pak. J. Agri. Sci. 58:1323-1336.

[Received 21 Jan 2021; Accepted 30 Jun 2021; Published (online) 21 Sep 2021] 
considered a scientific methodology to characterize grapes based on morphological, pomological and phenological traits (Ates et al., 2011). It is a basic tool which is being used for a long time in genotypes certification programs, monitoring genetic quality and for the preservation of endangered species (Dilli et al., 2014). Moreover, it is helpful to find the relationship among genotypes, recognizing genotypes, identifying pitfalls during collection, management strategies and identify agronomic interest genes (Khadivi et al., 2019; Blanco et al., 2007; Ergul et al., 2006). For characterization in grapes, several multivariate techniques like principal components analysis and cluster analysis are being used for qualitative and quantitative analysis (Leão et al., 2011). These techniques describe agronomical and morphological characters (Matheou et al., 1995), check relationships among genotypes related to traits (Boselli et al., 2000) and check the amount of variation between traits (Borges et al., 2008; Coelho et al., 2004).

The Potohar area is one of the enriched areas of Pakistan having grapes, olives and natural vegetation. Despite being a highly diverse area enriched with grapes diversity, it is considered a neglected area of Pakistan with low attention is given to characterize grapes found in this area. The grapes genotypes found in this area belong to different origins, some are wild native to this region while some are acclimatized from different regions of the world (Akram et al., 2019). Moreover, pre-monsoon and monsoon rains at crop maturity and farmer priority towards exotic cultivars to earn an early high profit are causing the disappearance of the local genotypes.

Hence the present study was done to characterize grapes genotypes present in this area based on morphological qualitative traits, with the aim to check the morphological variation and relationship among exotic and local genotypes. Further, quantitative agronomic traits were also taken to evaluate superior genotypes and a phenology calendar was developed to evaluate early, mid and late genotypes. This detailed study of morphological qualitative and quantitative traits will also be helpful to prevent disappearing local cultivars, for the preservation of germplasm and future breeding programs.

\section{MATERIALS AND METHODS}

Details of the experimental site: The genotypes collection was conducted from the Potohar region, located in the northern zone of Punjab, Pakistan. Potohar Zone lies in a range between $32.5^{\circ} \mathrm{N}$ to $34.0^{\circ} \mathrm{N}$ Latitude and $72^{\circ} \mathrm{E}$ to $74^{\circ} \mathrm{E}$ Longitude (Rashid and Rasul 2011). This region is present between the Jhelum and Indus rivers with altitudes 600 to 800 $\mathrm{m}$. It extends from the north of the salt range towards the foothills of the Himalayas. The soil of this region is generally medium textured to clay-loam and has $\mathrm{pH}$ of 7.5 to 8.5 (Ahmad et al., 1990). The region is considered as a sub- mountainous area having semiarid climatic conditions. The average annual temperature of the region is $22.3^{\circ} \mathrm{C}$ with an average precipitation of $519 \mathrm{~mm}$ annually (http://en.climatedata.org/location/1308/). However minimum temperature in winter $2^{\circ} \mathrm{C}$ and maximum temperature $43^{\circ} \mathrm{C}$ in summer were recorded during the study. The location of Potohar in Pakistan is mentioned in Fig.1.

Plant materials: The study was carried out during 2017-2018 with 30 grapevine genotypes (exotic and local) obtained from the northern zone of Punjab, Pakistan. The genotypes included in the study were Regina, Kishmish, Early White, White Seedless, NARC Black, Saibi, Haita, Gola, Gol, Aesel, Taifi, Chakwal Selection, BRI-001, Italia, Perlet, King Ruby's, Vitro Black, Sultanina, Red Globe, Flame Tokay, Thomson Seedless, Flame Seedless, Chesselas-b, Superior, Muscat Hambourg, Danlas-b, Moscatol Romano, Sundar Khani, Cardinal and Italia Hybrid. All the exotic and local genotypes in the study were 5 to 6year old and their plants were developed from cutting. All the genotypes were collected from different sites of Potohar and were planted at Barani Agriculture Research Institute (BARI) for germplasm conservation. The management practices including pruning, plowing, irrigation, fertilizer, insecticides and pesticide application were similar for all plants.

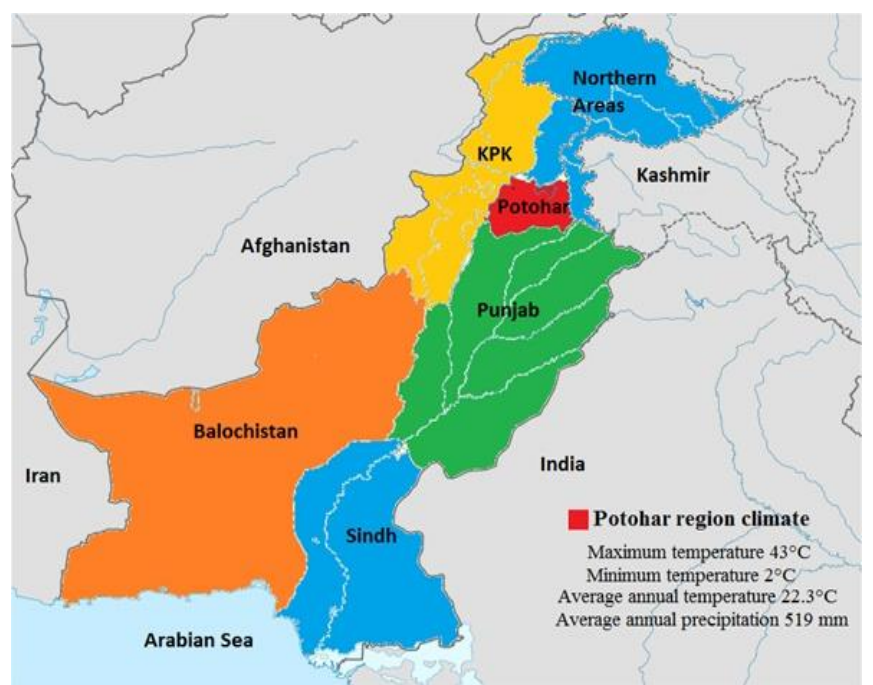

Figure 1. Map showing Potohar region of Pakistan and its climatic conditions.

Amphelographic qualitative traits: The mean values from six plants of each genotype were recorded for consecutive two years 2017-18 based on 43 ampelographic traits that is shown in Table 1. These traits were selected from the given descriptors as prescribed by International Plant Genetic Resources Institute (IPGRI UPOV 1997).

Quantitative traits: For the evaluation of superior agronomic traits, eight parameters including bunch length, bunch width, bunch weight, peduncle length, the weight of 10 berries, 
Table 1. List of forty-three amphelographic traits selected from IPGRI, OIV descriptor

\begin{tabular}{|c|c|c|c|}
\hline Amphelographic traits & Abbreviation & Amphelographic traits & Abbreviation \\
\hline 1. Young shoot: Form of tip & FT & 23. Mature leaf: Shape of teeth & ST \\
\hline 2. Young shoot: Anthocyanin coloration of tip & $\mathrm{ACP}$ & 24. Mature leaf: General shape of petiole sinus & GSPS \\
\hline 3. Young shoot: Density of prostrate hairs on tip & DPHT & 25. Mature leaf: Tooth at petiole sinus & TPS \\
\hline 4. Young shoot: Density of erect hairs on tip & DEHT & 26. Mature leaf: Petiole sinus limited by veins & PSLV \\
\hline 5. Shoot: Colour of dorsal side of internode & CDI & 27. Mature leaf: Shape of upper lateral sinus & SULS \\
\hline 6. Shoot: Colour of ventral side of internode & CVI & 28. Mature leaf: Depth of upper lateral sinus & DULS \\
\hline 7. Shoot: Colour of dorsal side of node & CDN & $\begin{array}{l}\text { 29. Mature leaf: Density of prostrate hairs } \\
\text { between veins }\end{array}$ & ML: DPHBV \\
\hline 8. Shoot: Colour of ventral side of node & CVN & $\begin{array}{l}\text { 30. Mature leaf: Density of erect hairs between } \\
\text { veins }\end{array}$ & ML: DEHBV \\
\hline 9. Shoot: Density of erect hairs on node & DEHN & $\begin{array}{l}\text { 31. Mature leaf: Density of prostrate hairs on } \\
\text { main veins }\end{array}$ & ML: DPHMV \\
\hline 10. Shoot: Density of erect hairs on internode & DEHI & $\begin{array}{l}\text { 32. Mature leaf: Density of erect hairs on main } \\
\text { veins }\end{array}$ & ML: DEHMV \\
\hline 11. Shoot: Density of prostrate hairs on node & DPHN & $\begin{array}{l}\text { 33. Mature leaf: Length of petiole compared to } \\
\text { middle vein }\end{array}$ & LPCMV \\
\hline 12. Shoot: Density of prostrate hairs on internode & DPHI & 34. Woody shoot: Surface & WS \\
\hline 13. Shoot: Number of consecutive tendrils & NCD & 35. Shoot: Main Color & $\mathrm{MC}$ \\
\hline 14. Shoot: Length of tendril & $\mathrm{LT}$ & 36. Bunch density & BD \\
\hline 15. Young leaf: Color of upper surface & CUS & 37. Berry: Shape & BS \\
\hline $\begin{array}{l}\text { 16. Young leaf: Density of prostrate hairs between } \\
\text { veins }\end{array}$ & YL: DPHBV & 38. Berry: Presence of seeds & PS \\
\hline 17. Young leaf: Density of erect hairs between veins & YL: DEHBV & 39. Berry: Skin color & $\mathrm{SC}$ \\
\hline $\begin{array}{l}\text { 18. Young leaf: Density of prostrate hairs on main } \\
\text { veins }\end{array}$ & YL: DPHMV & 40. Berry: Anthocyanin coloration of flesh & $\mathrm{ACF}$ \\
\hline 19. Young leaf: Density of erect hairs on main veins & YL: DEHMV & 41. Berry: Juiciness of flesh & JF \\
\hline 20. Mature leaf: Shape of blade & SB & 42. Berry: Ease of detachment from pedicel & EDP \\
\hline 21. Mature leaf: Number of lobes & NL & 43. Berry: Taste & $\mathrm{T}$ \\
\hline $\begin{array}{l}\text { 22. Mature leaf: Anthocyanin coloration of main } \\
\text { veins on upper side of blade }\end{array}$ & $\mathrm{ACVB}$ & & \\
\hline
\end{tabular}

number of berry in bunch, berry length and berry width were noted. Fruit bunches were collected from three trees of each genotype and all observations were taken as triplicate replicates for conformation of data analysis.

Phenological traits: For the evaluation of early maturing genotypes, different phenology parameters were examined from bud burst to fruit harvest. The traits noticed were time of budburst, time of 1st leaf emergence, time of inflorescence emergence and time of harvest. All parameters were observed when $50 \%$ of the plants of each genotype showed its physiological responses. Based on these parameters phenological calendar was developed.

Statistical analysis: The qualitative morphological traits were analyzed by principal component analysis (PCA) and cluster analysis was developed on the basis of dissimilarity using XLSTAT (2018) software. However, for the evaluation of superior genotypes based on qualitative traits, the data were subjected to analysis of variance (ANOVA) and Fisher's least significant differences were calculated following a significant $(\mathrm{P} \leq 0.05) \mathrm{F}$ test.

\section{RESULT}

PCA of grape genotypes based on qualitative traits: A scree plot was developed in PCA based on 44 morphological quantitative traits of 30 grapes genotypes as shown in Fig 2. The scree plot showed the estimated eigenvalues and cumulative variations found in grapes genotypes. In the scree plot, the eigenvalues up to the first seven factors decreased sharply while the cumulative variation increased sharply up to the first seven factors. Factor F1 had a maximum eigenvalue (8.141) with cumulative variability of $18.503 \%$.

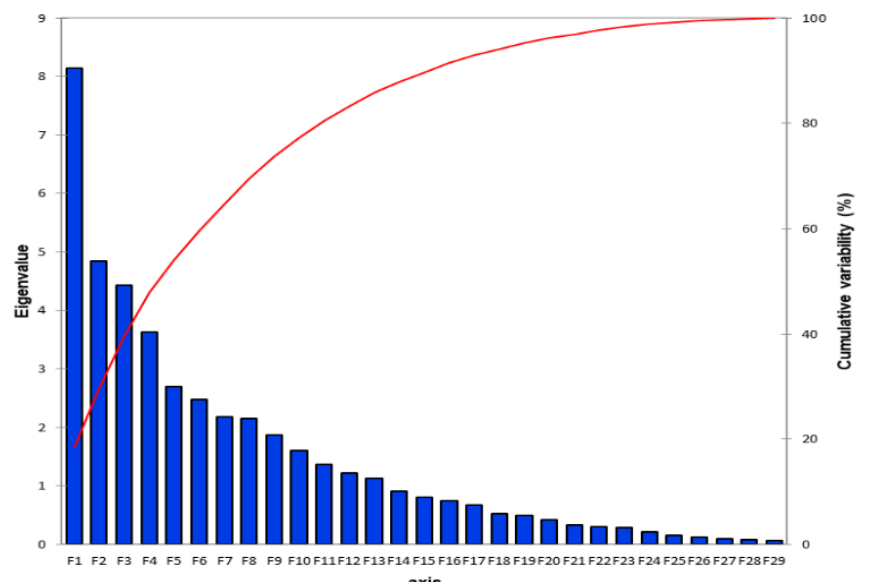

Figure 2.PCA of morphological qualitative traits of grape genotypes grown in northern zones of Punjab, Pakistan. 
Similarly, F2, F3, F4, F5, F6 and F7 have eigenvalues (4.848), (4.436), (3.630), (2.707), (2.481) and (2.187) with their cumulative variability $(29.522 \%),(39.603 \%),(47.853 \%)$, $(54.006 \%),(59.644 \%)$ and $(64.616 \%)$, respectively. After that, there was a steady increase in the cumulative variability up to $100 \%$ for F29. Phenotypic variations of mature leaf characters' ventral and dorsal sides are shown in Figures 3 and 4 , respectively.

In the eigenvector analysis of grapes variables, high variability $(64.616 \%)$ was controlled by the first seven vectors
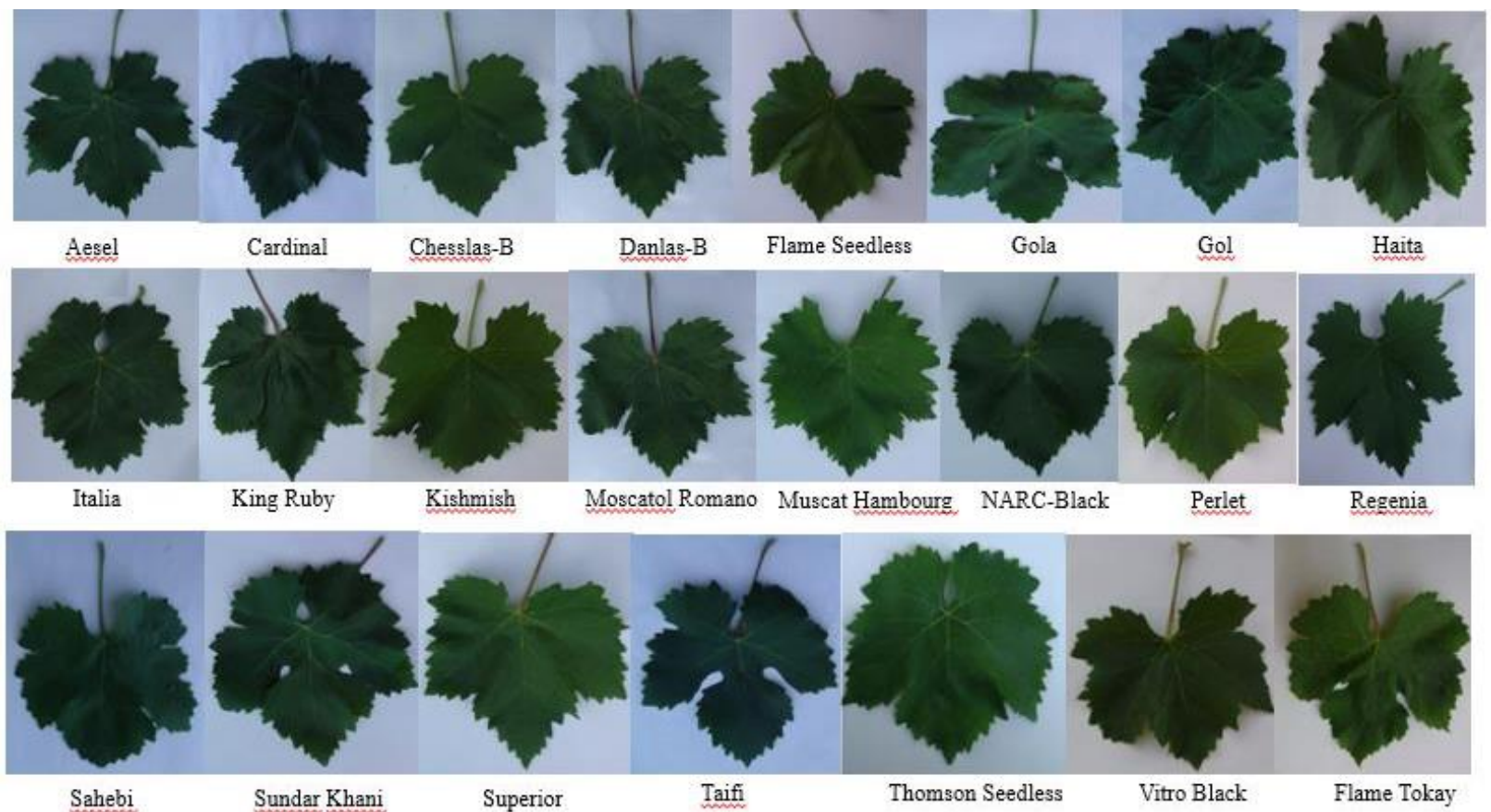

Figure 3. Phenotypic variations of characters observed in upper surface of mature leaves grapes genotypes grown in northern zones of Punjab, Pakistan.
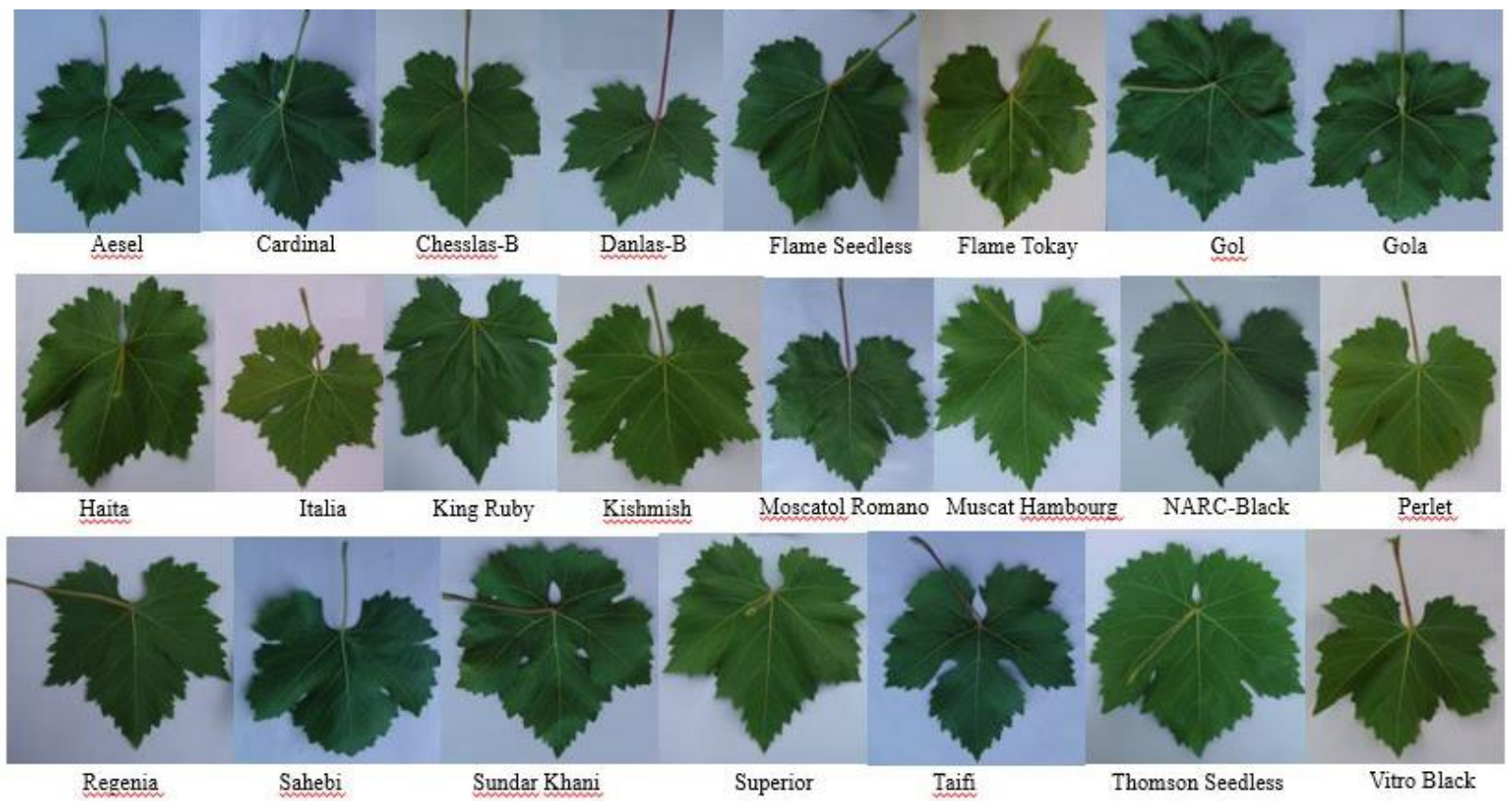

Figure 4. Phenotypic variations of characters observed in lower surface of mature leaves of grapes genotypes grown in northern zones of Punjab, Pakistan. 
(PC-1 to PC-7). The first vector or PC-1 covered maximum diversity of $18.503 \%$. It includes the contributory morphological qualitative parameters as shown in Table 2. In PC-1 maximum diversity was controlled by mature leaf variables ML: DPHMV, ML: DPHMV, and ML: DEHMV. In young leaf characteristics, maximum contributions were of variables YL: DPHBV, YL: DPHMV and YL: DEHMV. While in shoot characteristics, S: DPHN and S: DEHN variables showed maximum contribution. Similarly, second eigenvector or PC-2 controlled (11.018\%) diversity having

Table 2. PCA of forty-three morphological traits of 30 grapes genotypes grown in northern zones of Punjab, Pakistan.

\begin{tabular}{|c|c|c|c|c|c|c|c|}
\hline & F1 & F2 & F3 & F4 & F5 & F6 & F7 \\
\hline YS: FT & -0.395 & 0.332 & 0.139 & 0.699 & -0.101 & -0.230 & -0.125 \\
\hline YS: ACT & 0.395 & -0.645 & -0.391 & 0.216 & 0.151 & 0.196 & -0.004 \\
\hline YS: DPHT & 0.358 & 0.697 & -0.261 & 0.204 & -0.297 & -0.036 & -0.048 \\
\hline YS: DEHT & 0.325 & 0.575 & -0.168 & 0.053 & -0.414 & 0.212 & -0.120 \\
\hline S: CDSI & 0.110 & -0.463 & -0.618 & -0.121 & 0.116 & -0.067 & 0.058 \\
\hline S: CVSI & -0.085 & -0.565 & 0.046 & 0.187 & 0.028 & 0.144 & -0.034 \\
\hline S: CDSN & 0.295 & -0.370 & -0.091 & -0.126 & -0.100 & 0.273 & -0.146 \\
\hline S: CVSN & 0.093 & -0.585 & -0.168 & -0.092 & -0.287 & -0.032 & -0.256 \\
\hline S: DEHN & 0.626 & 0.260 & -0.441 & 0.143 & 0.058 & -0.006 & 0.328 \\
\hline S: EHI & 0.449 & 0.538 & -0.280 & 0.020 & 0.083 & 0.153 & 0.053 \\
\hline S: DPHN & 0.674 & 0.234 & -0.414 & -0.284 & 0.001 & 0.146 & 0.083 \\
\hline S: DPHI & 0.561 & 0.428 & -0.564 & -0.097 & 0.187 & 0.019 & 0.196 \\
\hline S: NCT & 0.104 & -0.182 & 0.437 & 0.367 & 0.148 & 0.044 & 0.586 \\
\hline S: LoT & 0.434 & -0.147 & 0.039 & 0.198 & 0.069 & 0.303 & -0.502 \\
\hline YL: CUS & 0.664 & -0.447 & -0.269 & -0.003 & -0.249 & 0.117 & -0.083 \\
\hline YL: DPHBV & 0.845 & 0.217 & -0.156 & 0.178 & 0.023 & -0.179 & 0.066 \\
\hline YL: DEHBV & 0.572 & -0.207 & 0.015 & 0.076 & 0.239 & 0.274 & 0.288 \\
\hline YL: DPHMV & 0.784 & -0.127 & 0.106 & -0.053 & -0.399 & -0.123 & 0.005 \\
\hline YL: DEHMV & 0.783 & 0.075 & 0.206 & 0.104 & -0.326 & 0.027 & -0.006 \\
\hline ML: SoB & -0.241 & 0.298 & -0.229 & -0.360 & 0.339 & 0.483 & 0.016 \\
\hline ML: NoL & 0.036 & -0.240 & -0.473 & 0.223 & -0.037 & -0.470 & 0.250 \\
\hline ML: ACMVUSB & 0.115 & -0.060 & -0.418 & 0.386 & -0.019 & -0.041 & 0.341 \\
\hline ML: SoT & 0.095 & -0.267 & -0.026 & -0.128 & -0.030 & 0.533 & 0.381 \\
\hline ML: GSPS & -0.186 & 0.431 & -0.280 & -0.080 & 0.461 & 0.100 & 0.022 \\
\hline ML: TPS & -0.018 & 0.283 & -0.418 & 0.372 & 0.473 & -0.098 & -0.049 \\
\hline ML: PSLV & -0.112 & 0.383 & -0.053 & -0.027 & -0.141 & 0.512 & -0.532 \\
\hline ML: SULS & 0.027 & 0.052 & 0.062 & -0.087 & 0.379 & -0.144 & -0.179 \\
\hline ML: DULS & -0.133 & 0.120 & -0.052 & 0.710 & -0.159 & 0.073 & -0.164 \\
\hline ML: DPHBV & 0.364 & 0.598 & 0.400 & -0.224 & -0.008 & -0.212 & -0.015 \\
\hline ML: DEHBV & 0.535 & 0.220 & 0.371 & -0.111 & -0.040 & -0.240 & 0.162 \\
\hline ML: DPHMV & 0.823 & -0.161 & 0.206 & -0.171 & 0.222 & -0.129 & -0.283 \\
\hline ML: DEHMV & 0.766 & -0.120 & 0.339 & -0.216 & 0.211 & -0.239 & -0.162 \\
\hline ML: DPHMV & 0.818 & -0.175 & 0.206 & -0.197 & 0.190 & -0.165 & -0.289 \\
\hline ML: LPCMV & 0.071 & 0.098 & 0.049 & 0.666 & 0.270 & 0.367 & -0.078 \\
\hline WS: S & 0.274 & -0.371 & 0.284 & 0.051 & 0.268 & 0.035 & 0.130 \\
\hline WS: MC & 0.559 & -0.021 & 0.328 & 0.138 & -0.056 & 0.347 & 0.078 \\
\hline Bh: Den & -0.181 & 0.053 & 0.269 & -0.543 & 0.340 & -0.201 & 0.166 \\
\hline Ber: Size & 0.209 & -0.218 & -0.034 & 0.460 & 0.509 & 0.045 & -0.274 \\
\hline Ber: Shp & -0.315 & 0.057 & 0.094 & -0.375 & -0.181 & 0.294 & 0.010 \\
\hline Ber: SC & 0.239 & 0.158 & 0.756 & 0.178 & 0.151 & 0.266 & 0.141 \\
\hline Ber: ACF & 0.079 & 0.139 & 0.743 & 0.305 & 0.096 & 0.226 & 0.211 \\
\hline Ber: JF & 0.017 & -0.104 & 0.077 & 0.402 & 0.162 & -0.412 & -0.299 \\
\hline Ber: EDP & 0.165 & 0.031 & 0.158 & 0.218 & -0.504 & -0.130 & 0.161 \\
\hline Ber: Tst & -0.222 & -0.380 & -0.066 & 0.127 & -0.332 & 0.145 & 0.148 \\
\hline Variability (\%) & 18.503 & 11.018 & 10.081 & 8.251 & 6.153 & 5.638 & 4.972 \\
\hline
\end{tabular}


responsible variables YS: DPHT, ML: DPHBV, YS: DEHT and S: EHI, respectively. While PC-3 covered (10.081\%) diversity with the highest loading variables including Ber: SC and Ber: ACF, respectively. The fourth component possessed $8.251 \%$ variability and a maximum contribution of ML: DULS, YS: FT and ML: LPCMV variables. The fifth vector revealed the maximum contribution of variables ML: TPS and ML: GSPS. However, the sixth vector showed the maximum contribution of variables ML: SOT and ML: PSLV while the seventh variable depicted maximum contribution of S: NCT as shown in Table 2. The variations present in bunches is presented in Figure 5.

PCA plots for qualitative morphological traits and grape genotypes: PCA plot developed based on 44 morphological traits divided the variables into four quadrants (Fig. 6). This plot depicts that grapes variables near to each other are closely
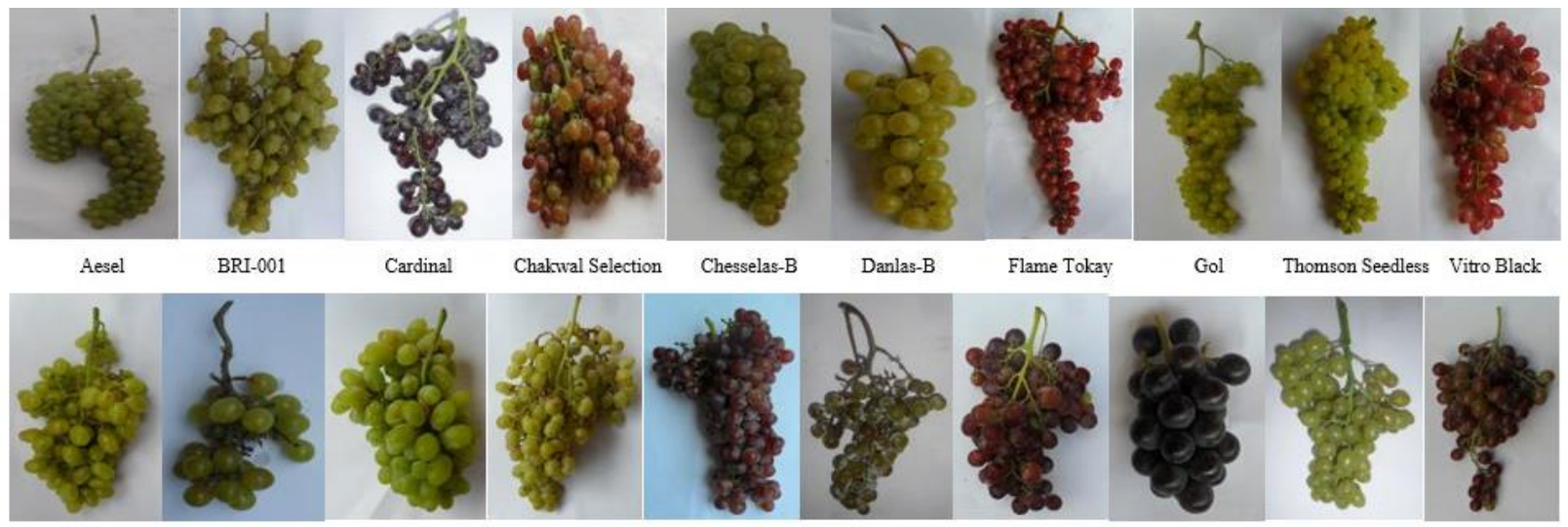

Chakwal Selection Chesselas-B Danlas-B

Flame Tokay

Gol Thomson Seedless Vitro Black

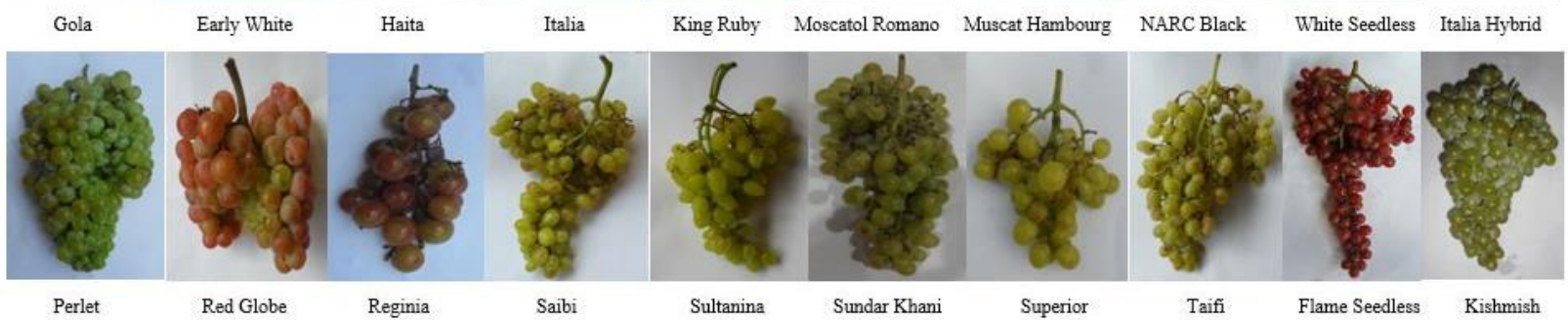

Figure 5. Variations observed in bunch characteristics (size, color, shape) of grape genotypes grown in northern zones of Punjab, Pakistan.

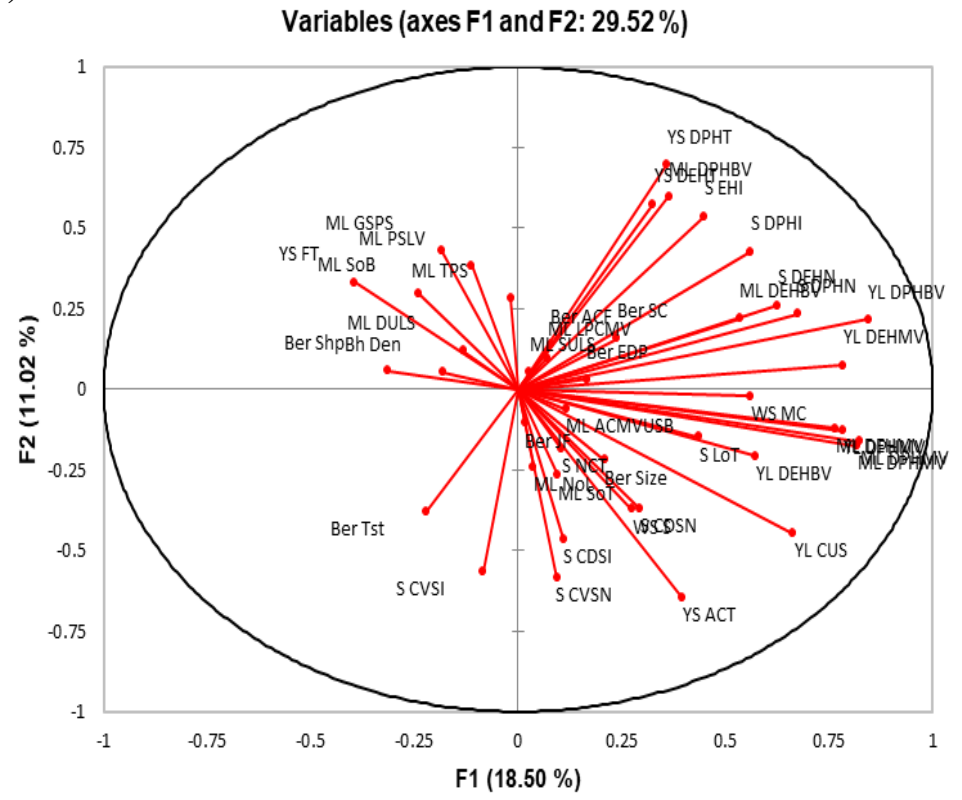

Figure 6.PCA plot of qualitative morphological traits for grape genotypes grown in northern zones of Punjab, Pakistan. 
related to each other have similar characteristics and have less contribution in diversity. While variables away from the center of the axis and variables present away from each other showed a high level of variations in grapes genotypes. In the PCA plot of variables, there were 15 variables that were present at the upper right quadrant of the plot. Out of these 15 variables, five variables Ber: ACF, Ber: SC, ML: LPCMV, Ber: EDP and ML: SULS were present near to the center of the axis. While ten variables, YS: DPHT, YS: DEHT, ML: DPHBV, S: EHI, S: DPHI, S: DPHN, S: DEHN, ML: DEHBV, YL: DPHBV and YL: DEHMV were far from the center and are responsible for variations in the grapes genotypes.

There were only two variables Ber: Tst and S: CVSI which were present at the lower left quadrant of the plot. It showed that these two variables had close relation between them but have negative relations with the variables at the upper right side of the plan. There were 19 variables present in the lower right side of the quadrant that had a strong relation between them and was closely associated with each other. Similarly, there were eight variables present in the upper left side of PCA plot which was closely related to each other. However, they were present at less distance from the center which showed that these variables had less contribution in variation as compared to variables present in the upper right quadrant of the plot. Similarly, there were 19 variables present in the lower right quadrant of the plot which had a strong association among them. The variable YS: DPHT on the upper right side and YS: ACT at the lower right side distinguished the cultivars more as compared to other variables.

PCA biplot of 44 qualitative morphological traits and 30 grape genotypes: A biplot (Fig. 7) showed the relationship between the genotypes and morphological variables. The results revealed that 15 qualitative traits or variables (Ber: ACF, Ber: SC, ML: LPCMV, Ber: EDP, ML: SULS, YS: DPHT, YS: DEHT, ML: DPHBV, S: EHI, S: DPHI, S: DPHN, S: DEHN, ML: DEHBV, YL: DPHBV and YL: DEHMV) had a strong correlation with genotypes Aesel, Early White, Sundar Khani, Flame Seedless, Muscat Hambourg and NARC Black and these characters had their positive contribution in these genotypes which included them in a similar group. In the opposite direction, at the left lower quadrant there were only two morphological traits Ber: Tst and S: CVSI which were mostly similar in genotypes White seedless, Haita, Chakwal Selection, Flame Tokay, Perlet, Saibi, Danlas- B, Regina and Vitro Black present in this quadrant.

The morphological variables present in the upper left side quadrant had a strong correlation with genotypes present in this quadrant. Similarly, the variables present on the lower

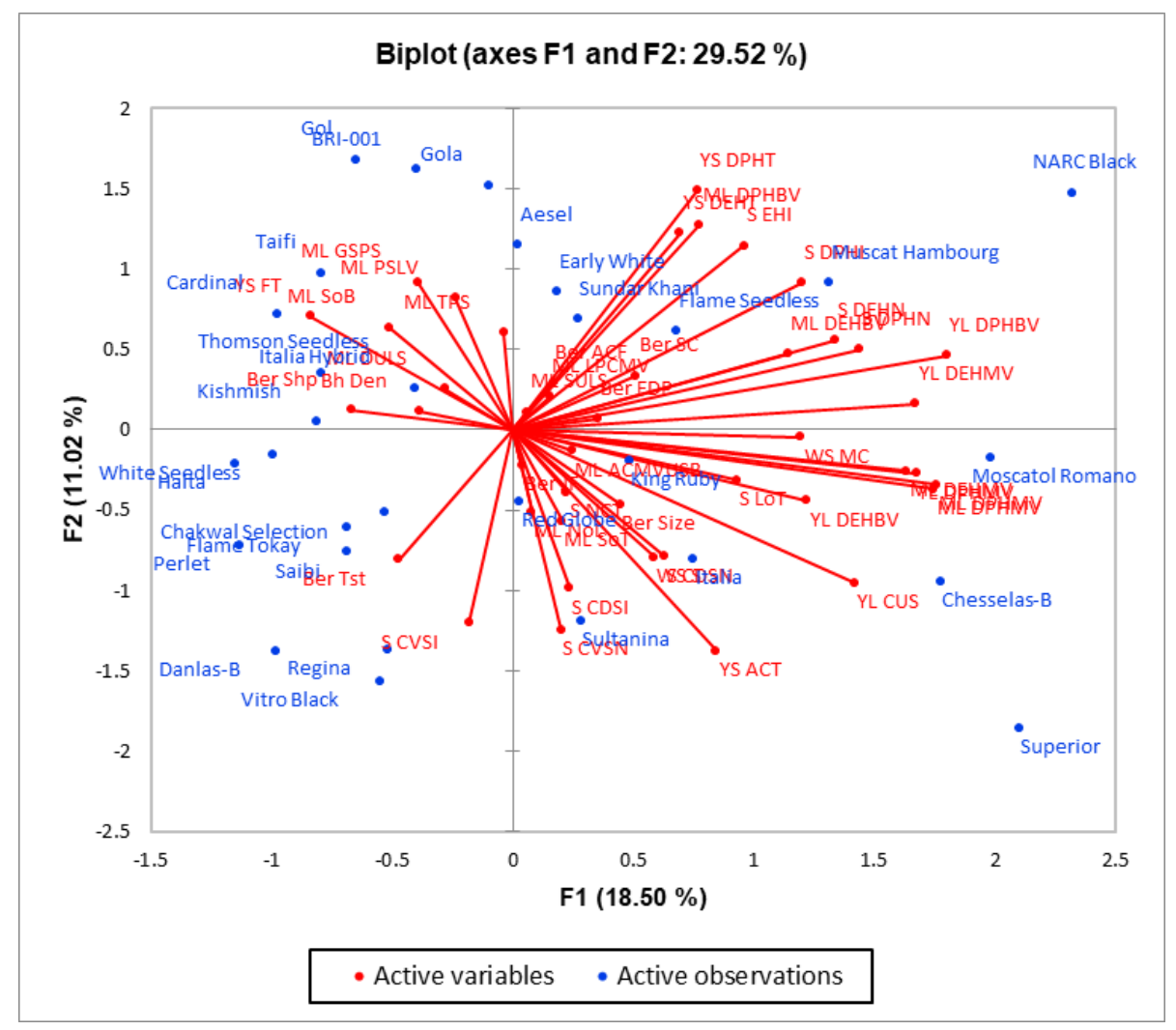

Figure 7. PCA biplot of 30 grape genotypes for qualitative morphological traits. 


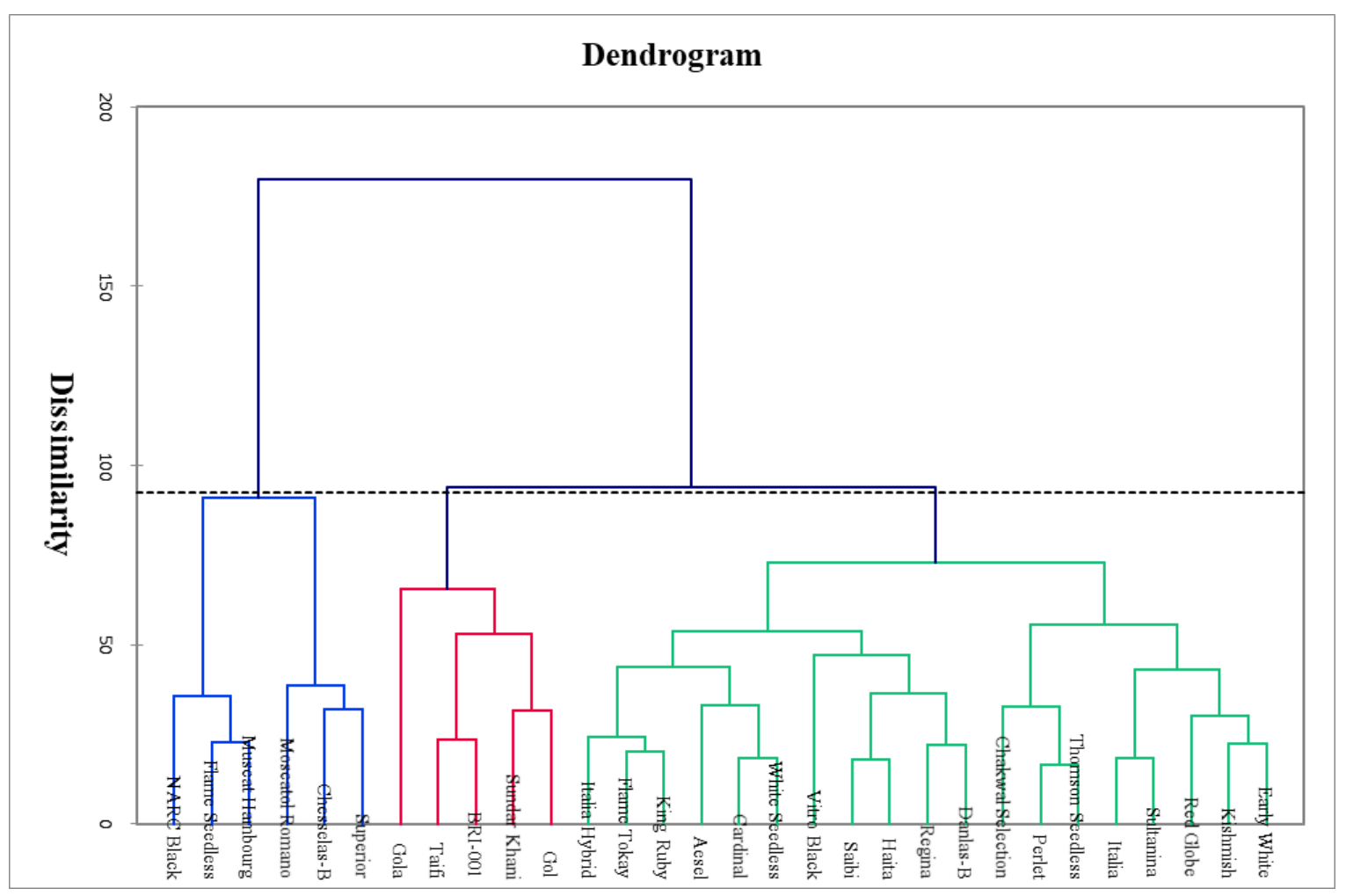

Figure 8. Dendrogram representing the relationship of 30 grapes genotypes based on morphological traits growing in northern zones of Punjab, Pakistan.

right side had a strong correlation with genotypes present in a similar quadrant. However, these two quadrants had a negative correlation between them. The results also told that grapes variables present near to the center of the axis were closely related to each other and had less contribution in diversity. While variables away from the center of the axis showed a high level of variations in grapes genotypes. Similarly, the genotypes close to each other were more similar in characteristics as compared to genotypes that were away like Chesslas-B which was present separately in the lower right quadrant (Fig. 7).

Cluster analysis of 30 grape genotypes based on morphological qualitative traits: Based on 44 morphological qualitative traits, 30 grape genotypes present in the northern zone of Punjab, Pakistan was divided into two main groups Group-1 and Group-2 (Fig. 8). These groups were further divided into classes. Group-1 contained only one class with two subclasses. While Group-2 further contained two classes in it with further subclasses. The variations present within the class were $81.72 \%$ while the variations present between classes were $18.28 \%$. In class 1 , there were six genotypes which were further divided into two sub-classes and in each subclass, there were three genotypes. Subclass 1, consisted of NARC Black, Flame Seedless and Muscat Hambourg while subclass 2 consisted of Moscatol Romano, Chesslass-B and Superior. These six genotypes were similar to each other but were significantly different from Group 2 genotypes based on morphological quantitative traits.

In Group-2, there were two main classes present; Class 1 consisted of five genotypes Gola, Taifi, BRI-001, Sundar Khani and Gol. However, Gola showed little variation among these genotypes. In Group-2, Class 2 was the largest class having 19 genotypes in it. This class was further divided into two sub-classes and each subclass was further divided into two sub sub classes based on similarity. Group-2, sub-class 1 consisted of 11 genotypes. Sub sub-class 1 was comprised of six genotypes Italia Hybrid, Flame Tokay, King Ruby's, Aesel, Cardinal and White Seedless. While sub sub-class 2 was comprised of five genotypes: Vitro Black, Saibi, Haita, Regina and Danlas-B. However, Group-2, sub-class 2 consisted of eight genotypes. In sub sub class 1 , there were three genotypes Chakwal Selection, Perlet and Thomson seedless while in sub sub-class 2, there were five genotypes Italia, Sultanina, Red Globe, Kishmish and Early White. The genotypes in each sub sub-class were most similar to each other.

Evaluation of grape genotypes based on quantitative traits: As fruit agronomic traits are greatly affected by the environment, however, they are used for grapes classification and are also of great importance for breeding new cultivars. The quantitative fruit characters recorded were bunch length, bunch width, bunch weight, peduncle length, weight of ten 
berries, number of berry in bunch, berry length and berry width (Table 3). All characters were significantly different from each other. Bunch length varied from $(27.50$ to $11 \mathrm{~cm})$ in the observed accessions. Large fruit bunches were found in Gola, Saibi, Sultanina-C and Thomson seedless respectively while the smallest bunch was of Haita cultivar. Similarly, maximum bunch width was noted in Taifi $(13.75 \mathrm{~cm})$ while minimum bunch width was found in Chesslas-B $(5 \mathrm{~cm})$. Bunch weight significantly varied from 583.56 to $77.10 \mathrm{gm}$. Maximum bunch weights were recorded in Kishmish (583.56 gm), Haita (579.50 gm) and Gola (556.50 gm) respectively. Peduncle lengths varied from 6.50 to $1.55 \mathrm{~cm}$. The weight of ten berries was also done separately along with bunch weight. The maximum weight of ten berries was obtained in Gola (53.70 gm) as bunch weight was also maximum in this cultivar while minimum weight was examined in Thomson Seedless berries ( $9.70 \mathrm{gm})$.

Maximum number of berries varied from 354 to 28. Thomson seedless cultivar contained maximum berries which were small in size but large in number while NARC Black genotype has large berries in size but few in number. Maximum berry length was observed in Gola $(27.37 \mathrm{~mm})$ and Sultanina-C $(25.19 \mathrm{~mm})$ respectively. Berry diameter was found in the range from 18.06 to $10.75 \mathrm{~mm}$ where larger berry widths were noted in Danlas-B (18.06 mm), King's Ruby (18 $\mathrm{mm})$ and Gola $(17.98 \mathrm{~mm})$ respectively.

Phenological calendar of 30 genotypes grown in northern zones of Punjab, Pakistan based on their phenological stages: For the evaluation of early, middle and late maturing genotypes, five phenological stages of each genotype were

Table 3. Fruit characteristics of grapes grown in northern zones of Punjab, Pakistan.

\begin{tabular}{|c|c|c|c|c|c|c|c|c|}
\hline Varieties & $\begin{array}{l}\text { Bunch } \\
\text { length }\end{array}$ & $\begin{array}{l}\text { Bunch } \\
\text { width }\end{array}$ & $\begin{array}{l}\text { Bunch } \\
\text { weight }\end{array}$ & $\begin{array}{l}\text { Peduncle } \\
\text { length }\end{array}$ & $\begin{array}{c}\text { Weight } \\
\text { of } 10 \\
\text { berries }\end{array}$ & $\begin{array}{l}\text { Number } \\
\text { of berry } \\
\text { in bunch }\end{array}$ & $\begin{array}{l}\text { Berry } \\
\text { length }\end{array}$ & $\begin{array}{l}\text { Berry } \\
\text { width }\end{array}$ \\
\hline F-value & $36.32 * *$ & $17.95^{*}$ & $151.00 * *$ & $50.69 * *$ & $65.06 * *$ & $17.48 * *$ & $11.78 * *$ & $32.17 * *$ \\
\hline Regina & $17.00 \mathrm{~d}-\mathrm{g}$ & $7.00 \mathrm{e}-\mathrm{g}$ & $150.65 \mathrm{j}-\mathrm{m}$ & $2.25 \mathrm{~g}-\mathrm{m}$ & $42.45 \mathrm{~b}$ & $28.33 \mathrm{kl}$ & $17.67 \mathrm{c}$ & $15.00 \mathrm{~d}-\mathrm{g}$ \\
\hline Kishmish & $20.23 \mathrm{~b}-\mathrm{d}$ & $12.33 \mathrm{ab}$ & $583.56 \mathrm{a}$ & $2.50 \mathrm{f}-1$ & $26.35 \mathrm{~cd}$ & $187.00 \mathrm{~d}$ & $18.58 \mathrm{c}$ & $15.71 \mathrm{c}-\mathrm{f}$ \\
\hline FlameTokay & $12.83 \mathrm{i}-\mathrm{k}$ & $9.93 \mathrm{~b}-\mathrm{e}$ & $193.90 \mathrm{~g}-\mathrm{k}$ & $3.00 \mathrm{~d}-\mathrm{g}$ & $14.80 \mathrm{~g}-\mathrm{i}$ & $86.33 \mathrm{gh}$ & $15.08 \mathrm{~cd}$ & $14.84 \mathrm{e}-\mathrm{g}$ \\
\hline Italia & $14.00 \mathrm{f}-\mathrm{k}$ & $9.75 \mathrm{~b}-\mathrm{e}$ & $271.10 \mathrm{ef}$ & $2.80 \mathrm{e}-\mathrm{h}$ & $38.00 \mathrm{~b}$ & $62.50 \mathrm{~h}-\mathrm{j}$ & $19.08 \mathrm{bc}$ & $17.85 \mathrm{ab}$ \\
\hline NARC Black & $12.00 \mathrm{jk}$ & $6.00 \mathrm{fg}$ & $77.70 \mathrm{n}$ & $1.95 \mathrm{j}-\mathrm{m}$ & $23.65 \mathrm{c}-\mathrm{e}$ & 28.001 & $16.75 \mathrm{~cd}$ & $16.04 \mathrm{~b}-\mathrm{f}$ \\
\hline Perlet & $21.00 \mathrm{bc}$ & $12.50 \mathrm{ab}$ & $205.67 \mathrm{f}-\mathrm{j}$ & $6.50 \mathrm{a}$ & $13.33 \mathrm{hi}$ & $180.00 \mathrm{de}$ & $16.00 \mathrm{~cd}$ & $17.00 \mathrm{a}-\mathrm{c}$ \\
\hline King Ruby & $17.50 \mathrm{c}-\mathrm{f}$ & $12.50 \mathrm{ab}$ & $196.70 \mathrm{~g}-\mathrm{k}$ & $1.90 \mathrm{k}-\mathrm{m}$ & $15.70 \mathrm{~g}-\mathrm{i}$ & $146.00 \mathrm{f}$ & $17.00 \mathrm{~cd}$ & $18.00 \mathrm{a}$ \\
\hline Vitro Black & $17.33 \mathrm{c}-\mathrm{f}$ & $9.90 \mathrm{~b}-\mathrm{e}$ & $227.85 \mathrm{f}-\mathrm{i}$ & $3.85 \mathrm{bc}$ & $26.35 \mathrm{~cd}$ & $72.50 \mathrm{hi}$ & $11.40 \mathrm{~d}$ & $15.47 \mathrm{c}-\mathrm{g}$ \\
\hline Sultanina & $22.33 \mathrm{~b}$ & $9.60 \mathrm{~b}-\mathrm{e}$ & $240.45 \mathrm{f}-\mathrm{h}$ & $2.70 \mathrm{e}-\mathrm{j}$ & $26.10 \mathrm{~cd}$ & $151.50 \mathrm{f}$ & $25.19 \mathrm{a}$ & $14.28 \mathrm{fg}$ \\
\hline Red Globe & $11.83 \mathrm{jk}$ & $5.75 \mathrm{fg}$ & $152.65 \mathrm{j}-\mathrm{m}$ & $2.90 \mathrm{e}-\mathrm{h}$ & $37.95 \mathrm{~b}$ & $58.00 \mathrm{ij}$ & $16.52 \mathrm{~cd}$ & $15.89 \mathrm{c}-\mathrm{f}$ \\
\hline Early White & $11.93 \mathrm{jk}$ & $5.55 \mathrm{fg}$ & $140.00 \mathrm{j}-\mathrm{n}$ & $3.90 \mathrm{~b}$ & $36.67 \mathrm{~b}$ & $43.67 \mathrm{j}-1$ & $18.00 \mathrm{c}$ & $15.87 \mathrm{c}-\mathrm{f}$ \\
\hline White Seedless & $14.00 \mathrm{f}-\mathrm{k}$ & $6.00 \mathrm{fg}$ & $142.67 \mathrm{j}-\mathrm{n}$ & $2.00 \mathrm{i}-\mathrm{m}$ & $20.10 \mathrm{~d}-\mathrm{g}$ & $64.00 \mathrm{~h}-\mathrm{j}$ & $16.25 \mathrm{~cd}$ & $16.04 b-f$ \\
\hline Thomson Seedless & $22.00 \mathrm{~b}$ & $10.50 \mathrm{a}-\mathrm{d}$ & $441.50 \mathrm{~b}$ & $2.50 \mathrm{f}-1$ & $9.70 \mathrm{i}$ & $354.00 \mathrm{a}$ & $11.61 \mathrm{~d}$ & $10.41 \mathrm{i}$ \\
\hline Flame Seedless & $16.50 \mathrm{e}-\mathrm{i}$ & $11.50 \mathrm{a}-\mathrm{c}$ & $346.55 \mathrm{~cd}$ & $2.85 \mathrm{e}-\mathrm{h}$ & $23.95 \mathrm{c}-\mathrm{e}$ & $162.50 \mathrm{~d}-\mathrm{f}$ & $16.79 \mathrm{~cd}$ & $16.01 \mathrm{~b}-\mathrm{f}$ \\
\hline Saibi & $22.40 \mathrm{~b}$ & $12.00 \mathrm{ab}$ & $390.33 \mathrm{bc}$ & $3.23 \mathrm{~b}-\mathrm{f}$ & $27.33 \mathrm{c}$ & $145.50 \mathrm{f}$ & $18.21 \mathrm{c}$ & $15.09 \mathrm{~d}-\mathrm{g}$ \\
\hline Haita & $11.00 \mathrm{k}$ & $11.70 \mathrm{a}-\mathrm{c}$ & $579.50 \mathrm{a}$ & $3.45 \mathrm{~b}-\mathrm{e}$ & $40.45 \mathrm{~b}$ & $160.00 \mathrm{ef}$ & $24.57 \mathrm{ab}$ & $16.74 \mathrm{a}-\mathrm{d}$ \\
\hline Chesselas-b & $13.15 \mathrm{~h}-\mathrm{k}$ & $5.00 \mathrm{~g}$ & $130.00 \mathrm{k}-\mathrm{n}$ & $3.90 \mathrm{~b}$ & $19.15 \mathrm{e}-\mathrm{h}$ & $74.00 \mathrm{hi}$ & $14.44 \mathrm{~cd}$ & $15.09 \mathrm{~d}-\mathrm{g}$ \\
\hline Superior & $14.00 \mathrm{f}-\mathrm{k}$ & $10.05 \mathrm{~b}-\mathrm{e}$ & $125.701-n$ & $1.80 \mathrm{~lm}$ & $24.70 \mathrm{c}-\mathrm{e}$ & $55.00 \mathrm{i}-\mathrm{k}$ & $18.24 \mathrm{c}$ & $16.67 \mathrm{a}-\mathrm{e}$ \\
\hline Gola & $27.50 \mathrm{a}$ & $11.00 \mathrm{a}-\mathrm{c}$ & $556.50 \mathrm{a}$ & $1.55 \mathrm{~m}$ & $53.70 \mathrm{a}$ & $112.50 \mathrm{~g}$ & $27.37 \mathrm{a}$ & $17.98 \mathrm{a}$ \\
\hline Muscat Hambourg & $15.25 \mathrm{e}-\mathrm{j}$ & $11.25 \mathrm{a}-\mathrm{c}$ & $309.35 \mathrm{de}$ & $2.20 \mathrm{~h}-\mathrm{m}$ & $26.20 \mathrm{~cd}$ & $112.50 \mathrm{~g}$ & $16.50 \mathrm{~cd}$ & $14.66 \mathrm{fg}$ \\
\hline Danlas-b & $13.50 \mathrm{~g}-\mathrm{k}$ & $5.50 \mathrm{fg}$ & $167.50 \mathrm{i}-1$ & $1.75 \mathrm{~lm}$ & $38.15 \mathrm{~b}$ & $45.00 \mathrm{j}-1$ & $19.05 \mathrm{bc}$ & $18.06 \mathrm{a}$ \\
\hline Moscatol Romano & $14.75 \mathrm{f}-\mathrm{j}$ & $9.75 \mathrm{~b}-\mathrm{e}$ & $173.50 \mathrm{~h}-1$ & $2.75 \mathrm{e}-\mathrm{i}$ & $26.55 \mathrm{~cd}$ & $64.50 \mathrm{~h}-\mathrm{j}$ & $16.30 \mathrm{~cd}$ & $15.60 \mathrm{c}-\mathrm{g}$ \\
\hline Sundar khani & $18.70 \mathrm{~b}-\mathrm{e}$ & $8.65 \mathrm{c}-\mathrm{f}$ & $439.05 \mathrm{~b}$ & $2.20 \mathrm{~h}-\mathrm{m}$ & $23.00 \mathrm{c}-\mathrm{f}$ & $159.00 \mathrm{ef}$ & $16.10 \mathrm{~cd}$ & $13.80 \mathrm{gh}$ \\
\hline Aesel & $17.00 \mathrm{~d}-\mathrm{g}$ & $11.50 \mathrm{a}-\mathrm{c}$ & $350.55 \mathrm{~cd}$ & $3.10 \mathrm{c}-\mathrm{f}$ & $17.00 \mathrm{f}-\mathrm{h}$ & $267.50 \mathrm{~b}$ & $13.79 \mathrm{~cd}$ & $10.75 \mathrm{i}$ \\
\hline Taifi & $17.30 \mathrm{c}-\mathrm{f}$ & $13.75 \mathrm{a}$ & $353.00 \mathrm{~cd}$ & $2.60 \mathrm{f}-\mathrm{k}$ & $23.50 \mathrm{c}-\mathrm{f}$ & $143.00 \mathrm{f}$ & $18.35 \mathrm{c}$ & $15.75 \mathrm{c}-\mathrm{f}$ \\
\hline Cardinal & $12.20 \mathrm{jk}$ & $7.60 \mathrm{~d}-\mathrm{g}$ & $94.20 \mathrm{mn}$ & $1.55 \mathrm{~m}$ & $20.00 \mathrm{~d}-\mathrm{g}$ & $48.50 \mathrm{i}-1$ & $15.40 \mathrm{~cd}$ & $15.05 \mathrm{~d}-\mathrm{g}$ \\
\hline Gol & $16.75 \mathrm{~d}-\mathrm{h}$ & $10.00 \mathrm{~b}-\mathrm{e}$ & $255.56 \mathrm{e}-\mathrm{g}$ & $3.70 \mathrm{~b}-\mathrm{d}$ & $15.30 \mathrm{~g}-\mathrm{i}$ & $219.00 \mathrm{c}$ & $14.60 \mathrm{~cd}$ & $12.15 \mathrm{hi}$ \\
\hline Italia Hybrid & $20.25 b-d$ & $10.25 \mathrm{~b}-\mathrm{e}$ & $172.10 \mathrm{~h}-\mathrm{j}$ & $2.65 \mathrm{~d}-\mathrm{i}$ & $19.95 \mathrm{e}-\mathrm{h}$ & $87.50 \mathrm{hi}$ & $15.25 \mathrm{~cd}$ & $14.05 \mathrm{f}-\mathrm{h}$ \\
\hline Chakwal Selection & $18.70 \mathrm{~b}-\mathrm{f}$ & $10.95 \mathrm{a}-\mathrm{c}$ & $439.05 \mathrm{~b}$ & $2.20 \mathrm{f}-1$ & $23.00 \mathrm{c}-\mathrm{g}$ & $158.00 \mathrm{ef}$ & $16.10 \mathrm{~cd}$ & $13.80 \mathrm{gh}$ \\
\hline BRI-001 & $19.80 \mathrm{~b}-\mathrm{e}$ & $11.75 \mathrm{a}-\mathrm{c}$ & $385.00 \mathrm{bc}$ & $3.00 \mathrm{c}-\mathrm{f}$ & $27.90 \mathrm{c}$ & $137.00 \mathrm{fg}$ & $17.85 \mathrm{c}$ & $14.20 \mathrm{e}-\mathrm{g}$ \\
\hline
\end{tabular}

*Means with same letters do not differ significantly at $\mathrm{p} 0.05$ by Tukey HSD test; $* *=$ Highly Significant $(\mathrm{P} \leq 0.01) ; *=$ Significant $(\mathrm{P} \leq 0.05) ; \mathrm{NS}=$ Non-Significant $(\mathrm{P} \geq 0.05)$ 
recorded at a specific time, like time of budburst, first leaf emergence, time of inflorescence, cap fall to fruit set and time of harvesting. The data of each stage was recorded when more than $60 \%$ of plants showed stage symptoms. The time of bud burst indicated great variation in observed genotypes as mentioned in Fig. 9. The time of budburst started in observed genotypes from the $1^{\text {st }}$ week of March and ends up to the $3^{\text {rd }}$ week of March depending upon the specific genotype. Early white and White seedless were the accessions which started bud burst in 1st week of March. However, Italia hybrid was the only genotype that started bud bursting at the end of 3rd week of March. It was also recorded that several genotypes started and completed their bud burst stage in $2^{\text {nd }}$ week of March (Kishmish, Italia, Vitro Black, Haita, Chesslas-B, Moscatol Romano and Chakwal Selection).

The first leaf emergence stage depicted great variations in leaf sprouting. This stage started from $2^{\text {nd }}$ week of March and ends at the start of the $4^{\text {th }}$ week depending upon the genotypes. Early White and White seedless genotypes started leaf emergence from the $2^{\text {nd }}$ week of March. Early White completed its stage this week while White Seedless completed its stage at the start of $3^{\text {rd }}$ week. In genotypes Flame Seedless, Aesel and Taifi, leaf emergence started from the $2^{\text {nd }}$ week of March and remained up to the middle of the $4^{\text {th }}$ week. Time of inflorescence was completed in Early White genotype up to start of 3rd week of March. It was the only accession that completed this stage earliest as compared to other accessions. This stage started from the start of $3^{\text {rd }}$ week and ends in the $1^{\text {st }}$ week of April depending upon the genotype.

Cap fall to fruit set was the longest stage which was found in grapes. In genotype Early White, this stage started earliest from $3^{\text {rd }}$ week of March followed by genotypes Regina, Flame Tokay, NARC Black, King's Ruby and White Seedless. While in genotypes Red Globe, Superior, Moscatol Romano, Aesel, Taifi, Italia Hybrid and BRI-001 cap fall started late in the first week of April. The fruit set stage was included up to when berries attained their maximum size. There were great variations observed between the accessions at this stage. Some genotypes attained their maximum size at the start of June while other genotypes attained their maximum berry size up to the middle of July depending on their maturity behavior. Regina, Perlet and Early White were the earliest mature genotypes that were harvested in the second week of June followed by genotypes Flame Tokay, White Seedless and Flame Seedless which matured in the third week of June. Sundar Khani, Aesel and Taifi were genotypes that mature at the last as compared to other genotypes under study. These cultivated were harvested in the third week of July so they were late mature genotypes. Kishmish, Cardinal and Moscatol

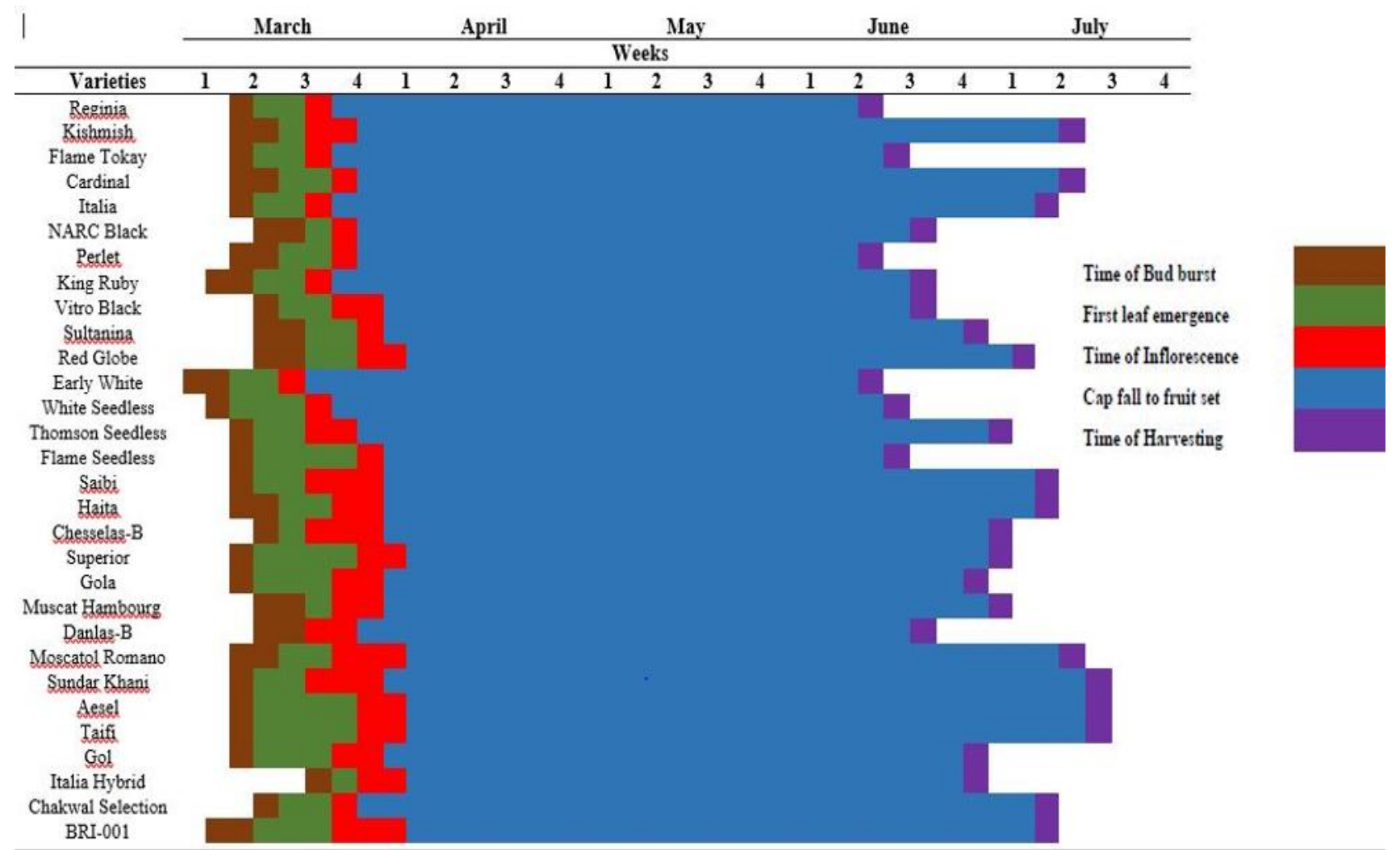

Figure 9. Phenological calendar of 30 genotypes grown in Potohar region of Pakistan based on different phenological stages. 
Romano were also late mature genotypes and were harvested at the end of the $2^{\text {nd }}$ week of July.

\section{DISCUSSION}

Morphological characterization of grapes genotypes based on qualitative and quantitative traits: Morphological characterization is one of the basic and simplest tools to differentiate genotypes based on visual observations. It is being used since Mendel's era and is still considered an important tool in this modern era for discrimination and separation of genotypes. Morphological characterization provides basic information about the traits. It is necessary to manage existing germplasm in vineyards for the development of new lines through breeding as breeding goals in fruits are to improve fruit weight, shape, color and inner quality (Guan et al., 2020). Morphological characterization provides superior results as we can determine more characteristics as compared to other characterization. Morphological characterization dominance should be taken into account while interpreting the number of characteristics examined (Atak et al., 2012).

In our study, morphological characterization was quite helpful to discriminate genotypes based on characteristics taken as prescribed by the descriptor of IPGRI. These characters showed variation among the grape genotypes grown in the Potohar region of Pakistan. The variables density of erect and prostrate hairs on young and mature leaves was the most prominent factor in our study which differentiated the genotypes based on dissimilarity. Similar findings were observed by (Dilli et al., 2014) who found the density of erect and prostrate hairs on mature leaves responsible for the discrimination of grape genotypes in their findings. Similar results were reported by (Ates et al., 2011) that the density of prostrate hair on young leaves played a significant role in the identification of grapevine genotypes. These characters showed significant variations in varieties grown in the northern zones of Punjab, Pakistan.

Based on these hair characteristics of young and mature leaves, genotypes in our study were divided into different subgroups. Genotypes in each subgroup were very similar in their morphological characters. In this comprehensive study of descriptors, certain characters including the density of prostrate hairs on main veins; density of erect hairs on main veins; erect hairs on internode; density of prostrate hairs between veins and density of erect hairs between veins played their anticipated role in the identification of the grape genotypes. These characters also played a major role in the construction of a dendrogram to evaluate the phylogenetic relationships of genotypes. Similar findings were observed by Knezovic et al. (2017) who selected 16 characteristics from OIV descriptor to identify ten grapes genotypes. Likewise, Atak et al., (2014) determined 55 morphological traits to check variability in nine grapes cultivars.
Mature leaf characters are also powerful tools for the identification of grapevines (Ates et al., 2011; Boselli et al., 2000). Depth of upper lateral sinus which is different among all genotypes is a mature leaf character that provides discriminative data in this study. These findings were also similar to Santiago et al. (2007) and Ortiz et al. (2004) who reported that mature leaf characters provide discriminative data for the identification and separation of genotypes. However certain mature leaves characters in our study such as the number of lobes, shape of teeth, petiole sinus limited by veins and density of erect hairs between veins were very similar in several genotypes and did not play a significant role in discrimination of the genotypes.

Morphological characters provide basic information about the traits. Traits that are related to the production of a crop like the number of berries, bunch size, berry weight, berry length and berry width can only be measured by taking physical observations which is possible to measure only by morphological characterizations. Further, this information is important for breeders which helps them to improve genotypes. The fruits traits are the major factors that determine crop productivity and are required for crop improvement. These factors also play a major role in breeding selection criteria for grape species (Vafaee et al., 2017). Davies and Savolainen, (2006) reported that morphological characters like berry length are highly correlated with changes in genetic characters. Grapes bunch and berry characters have their significant role in quality assessment especially in table grapes (Dilli et al., 2014). Variability related to bunch and berry was determined in the studied genotypes. The berry ripeness in grapes varies depending on their intent to use (Khan et al., 2009). Often characters like bunch size, berry size, weight, flavor and sweetness are used as indicators of grape maturity. Color alone is not the sole parameter for grapes harvesting (Jauron et al., 1997).

Berry size development directly depends upon water as it is the fundamental constituent of the grapes berry and it is 75$85 \%$ of the fruit weight (Khan et al., 2009). Berry length, width, weight and number of berries are directly involved in the production of crops and these parameters directly depend upon the genotype selection and environmental factors. In our findings, the highest berry length, width and bunch weight was observed in Gola was the local cultivar of the region. The reason to attain maximum berry length and width is that this genotype has well adapted itself to climate and has genetic characteristics. Environmental factors like soil, precipitation, temperature, humidity and their combination greatly influence grapes' quality (Ubalde et al., 2010). Quality includes the physical features like fruit shape, color and size which attract a consumer. The climatic variations in grape growing areas account for diversity in berry quality and other grapes products (Khan et al., 2009). Berry and bunch characters are also of great importance for breeders as they play their direct role in variety development and 
improvement. Further, the evaluation of morphological and agronomical traits in grapes is helpful in adopting superior varieties and these findings are helpful in the selection of bestperforming cultivars for a specific region based on fruit yield and quality attributes (Kuria et al., 2020).

Phenology of grapes genotypes grown in Potohar region: Grapes is one of the most cultivated crops of the world and are highly responsive to climatic and environmental variations. It is included in temperate fruits as it requires specific chilling hours to break its dormancy. This crop goes through several phenological stages during its life cycle like dormancy, bud break, first leaf emergence, inflorescence emergence, fruit set and fruit harvest (Poudel et al., 2010). Phenology is defined as a study of plant life cycle stages with its relation to climate (Schwartz 2013). It is also considered one of the key signs of climate change (Menzel et al., 2005). In past, grapes phenological stages like bud break, flowering and fruit maturity were used to check the climate variability (Jones et al., 2005)

Under the agro-climatic conditions of (Potohar) Pakistan, grapes go to dormancy during winter and the bud break starts in early March depending upon the genotypes. Phenology of grapes genotypes changes with climatic conditions. Temperature, precipitation, and humidity are responsible to change the phenology of grapes (Cleland et al., 2007; Chuine et al., 2003). The change in climatic conditions greatly affects the growth and yield of a plant. Under the climatic and environmental conditions of Potohar, it takes more than 90 days to mature. But at maturity, there is the problem of monsoon rains in the Potohar area of Pakistan which causes the berry rotting pathogens and splitting. The rains at maturity invite several fungal which ultimately destroy the yield. Our results were in harmony with other researchers who stated that narrowing the harvesting period in grapes is a severe problem that increases fungal problems in table grapes (Atak and Kahraman, 2012). Temperature changes during the phenological stage cause stress and can endanger a crop (Kalra 2008). Similar findings were observed by Singh et al., (2007) who said that change in temperature at any vegetative or reproductive stage severely affects the vine yield. Other climatic factors like rainfall or precipitation during a phenological stage can cause instability of grape crops (Jackson and Schuster, 2001). So, it is necessary to know about the grapes' genotypes which types of grapes are suitable for the specific region under specific climatic conditions (Jones et al., 2010). Climate greatly affects the physical and biological maturity of grapes (Akram et al., 2020).

The number of days required to complete phenological stages also includes genetic factors. Different genotypes mature at different times under the same environmental conditions. The varieties which take fewer days from bud burst to maturity earlier mature genotypes. Similarly, varieties that took more days to mature are known as late mature genotypes. In our study, genotypes Regina, Flame Tokay, Early White, Perlet,
White seedless and Flame seedless mature earlier in the middle of June. While Kishmish, Cardinal, Sundar Khani, Aesel and Moscatol Romano were late mature genotypes that mature at the end of July. The reason for these genotypes' maturation at different times is that early mature genotypes require less chilling hours to budburst as compared to late mature genotypes. Therefore, early mature genotypes take fewer days from bud burst stage to fruit harvest. Our finding had accordance with researchers Saniya et al., (2017); Gupta et al., (2015) and Mandelli et al., (2003) who found that early mature genotypes took less time from bud burst to fruit set while studying different grapes genotypes.

The adaption of a specific grape genotype depends upon its genetics and on its phenology behavior. Grapes phenology is a major component found for variety adaption to a specific environment (Duchene et al., 2010; Chuine, 2010). In grapes, it is considered that genotype or variety which adapts itself in a certain ecological condition had a high potential of yield while which are unable to adapt gave poor production and quality (Cvetkovic et al., 1999). Hence it is necessary to know a variety of phenological stages and climate of the site before the plantation of a vineyard. The climatic conditions like sunlight, rainfall and evaporation reflect the phenological process and grapes' ability in a specific place and affect its berry quality (Van Leeuwen et al., 2004).

Conclusion: According to morphological characters investigated in this study, great differences were noted among local and exotic genotypes. There were several characters, as described above, which played their specific part in the constitution of the morphological dendrogram. For example, characters from Mature leaf (density of prostrate hairs on main veins; density of erect hairs on main veins; density of prostrate hairs between veins; density of erect hairs between veins) characters from the shoot (erect hairs on internode; erect hairs on the node; density of prostrate hairs on node; density of prostrate hairs on internode) and characters from Young leaf (density of prostrate hairs between veins; density of erect hairs between vein; density of prostrate hairs on main veins; density of erect hairs on main veins) were greatly different among the studied genotypes. The results revealed that Regina, Perlet and Early White were the earliest mature genotypes that matured in the $2^{\text {nd }}$ week of June followed by genotypes Flame Tokay, White Seedless and Flame Seedless which matured in the $3^{\text {rd }}$ week of June. Local genotypes Sundar Khani, Aesel and Taifi matured in the last week of July. This study provided specific knowledge on some local grape genotypes, some of which are on the verge of extinction. Therefore, this study helps to prevent the disappearance of local varieties and preserve this collection of germplasm for future studies. 
Acknowledgments: We are grateful to Barani Agriculture Research Institute, Chakwal for a sample collection from the research station.

\section{REFERENCES}

Ahmad, S., M. Khan and M. Zaheer-ul-Ikram. 1990. Soil and water conservation and integrated land use in Pothwar, Pakistan. In: Akhtar ME, Nizami MI, editors. Soil physics: application under stress environments. Proceedings of the International Symposium on Applied Soil Physics in Stress Environments; Islamabad, Pakistan. Pakistan Agricultural Research Council; p. 301-312.

Akram, M.T., R.W.K. Qadri, M.J. Jaskani and F.S. Awan. 2019. Ampelographic and genetic characterization of grapes genotypes collected from Potohar region of Pakistan. Pak. J. Agri. Sci. 56:595-605.

Akram, M.T., R.W.K. Qadri, M.J. Jaskani and F.S. Awan. 2020. Phenological and physicochemical evaluation of table grapes germplasm growing under arid subtropical climate of Pakistan. Pak. J. Bot. 52(3), DOI: http://dx.doi.org/10.30848/PJB2020-3(7).

Atak, A. and K.A Kahraman. 2012. Breeding studies and new table grapes in Turkey. EJARD 2: 80-85.

Atak, A., A. Altındiçli, A. Gokşe and C. Ozer. 2012. Molecular and ampelographic characterization of some grape hybrids (Vitis vinifera L.). Afr. J. Agric. Res. 7:4596-4606.

Atak, A., K.A Kahraman and G Soylemezoglu. 2014. Ampelographic identification and comparison of some table grape (Vitis vinifera L.) clones, New Zeal.J. Crop Hort 42: 77-86.

Ates F., H. Coban, Z. Kara and A. Sabir. 2011. Ampelographic characterization of some grape cultivars (Vitis vinifera L.) grown in south-western region of Turkey. Bulg. J. Agric. Sci. 17:314-324.

Blanco C., T. Martinez and F.M. De Toda. 2007. Analysis of the intervarietal heterogeneity in the vine germplasm of La Rioja (Spain). Acta Hortic. 754:39-43.

Borges, R.M.E., N.P.D.S. Gonçalves, A.P.D.O. Gomes and E.O.D.S. Alves. 2008. Phenotypic divergence among table grapes accesses in the Brazilian semi-Arid. Pesqui. Agropecu. Bras. 43:1025-1030.

Boselli, M., C. Corso and A. Monaco. 2000. Ampelographic characterization of white grape varieties in Campania (Southern Italy) by multivariate analysis. Acta Hortic. 528:75-84.

Chuine, I. 2010. Why does phenology drive species distribution? Phil. Trans. R. Soc. B. 365: 3149-3160.

Chuine, I., K. Kramer and H. Hanninen. 2003. Plant development models. In: Schwartz MD, editor. Phenology: An Integrative Environmental Science. Dordrecht: Academic Publishers; p. 305-333.
Cleland, E.E., I. Chuine, A. Menzel, H.A. Mooney and M.D. Schwartz. 2007. Shifting plant phenology in response to global change. Trends Ecol. Evol. 22:357-365.

Coelho, I., L. Carneiro and R. Castro. 2004. Ampelometric comparison of wild vine Vitis vinifera L. populations and old grapevine cultivars of the south of Portugal. Cienc. Tec. Vitivinic. 19:1-12.

Cvetkovic, D., S. Branislava, S. Snezana and J. Joksimo. 1999. Effects of altitude on grape yield and quality in the cultivar Muscat Hamburg grown under the conditions of the Toplica grape growing sub region. J. Agric. Sci. 44:145-151.

Davies, T.J. and V. Savolainen. 2006. Neutral theory, phylogenies, and the relationship between phenotypic change and evolutionary rates. Evol. 60:476-483.

De Lorenzis, G., R. Chipashvili, O. Failla, and D. Maghradze. 2015. Study of genetic variability in Vitis vinifera L. germplasm by high-throughput Vitis18kSNP array: the case of Georgian genetic resources. BMC Plant Biol. 15:154.

Dilli, Y., U. Akay, M. Kesgin, M.S. Inan and G. Soylemezoglu. 2014. Comparison of ampelographic characteristics of some important grape varieties are grown in the Aegean Region, rootstock and clones. Turk. Agric. Nat. Sci. 7:1546-1553.

Duchene, E., F. Huard, V. Dumas, C. Schneider and D. Merdinoglu. 2010. The challenge of adapting grapevine varieties to climate change. Clim. Res. 41:193-204.

GOP, 2013. Agriculture Statistics of Pakistan. Ministry of Food Agriculture Livestock, Islamabad, Pakistan.

Guan, C., Y. Zhang, P. Zhang, S. Chachar, R. Wang, X. Du and Y. Yang. 2020. Germplasm conservation, molecular identity and morphological characterization of persimmon (Diospyros kaki Thunb.) in the NFGP of China. Sci. Hortic. 272:109490.

Gupta, N., K.S. Brar, M. Gill, N.K. Arora. 2015. Studies on variability, correlation and path analysis of traits contributing to fruit yield in grapes. Indian J. Plant Genet. Res. 28:317-320.

IPGRI, 1997. Descriptors for grapevine (Vitis spp.). International Union for the Protection of New Varieties of Plants, Geneva, Switzerland. Office Internationale de la Vigne et du Vin, Paris, France International Plant Genetic Resources Institute, Rome. p. 66.

Jackson, D.I. and D. Schuster. 2001. The Production of Grapes and Wine in Cool Climates. New Zealand: Gypsum Press and Daphne Brasell Associates Ltd. Wellington; p. 193.

Jauron, R., G. Nonnecke, D. Lewis and M. Gleason. 1997. Growing grapes in home garden. Iowa State University, University Extension, USA.

Jones, G.V., A.A. Duff, A. Hall and J.W. Myers. 2010. Spatial analysis of climate in winegrape growing regions in the western United States. Am. J. Enol. Viticult. 61: 313-326. 
Jones, G.V., E. Duchene, D. Tomasi, J. Yuste, O. Braslavska, H. Schultz, C. Martinez, S. Boso, F. Langellier, C. Perruchot and editors. 2005. Changes in European winegrape phenology and relationships with climate, in XIV International GESCO Viticulture Congress; Geisenheim, Germany; p. 54-61.

Kalra, N. 2008. Effect of increasing temperature on yield of some winter crops in North West India. Curr. Sci. 94: 8288.

Khadivi, A., A. Gismondi and A. Canini. 2019. Genetic characterization of Iranian grapes (Vitis vinifera L.) and their relationships with Italian ecotypes. Agroforest Syst. 93:435-447.

Khan, A.S., A. Malik, M. Pervez, B. Saleem, I. Rajwana, T. Shaheen and R. Anwar. 2009. Foliar application of lowbiuret urea and fruit canopy position in the tree influence the leaf nitrogen status and physico-chemical characteristics of Kinnow mandarin (Citrus reticulata Blanco). Pak. J. Bot. 41:73-85.

Khawale, R.N. and S.K. Singh. 2015. In vitro adventitive embryony in Citrus: A technique for Citrus germplasm exchange. Curr. Sci. 88: 1309-1311.

Knezovic, Z., A. Mandic, P, Nikic, J. Beljo, Jure and M.Z. Mihaljevic. 2017. Morphological and genetic characterization of vine grape cultivars of Herzegovina. CREBSS. 3: 1-9.

Kuria, D.N., A.B. Nyende and F.K. Rimberia. 2020. Evaluation of morphological and quality characteristics of introduced grape cultivars produced under greenhouse conditions in Kenya. Afr. J. Agric. Res. 15: 269-277.

Leao, P.C.D.S., C.D. Cruz and S.Y. Motoike. 2011. Genetic diversity of table grape based on morphoagronomic traits Sci. Agr. 68: 42-49.

Lorrain, B., K. Chira and P.L. Teissedre. 2011. Phenolic composition of Merlot and Cabernet-Sauvignon grapes from Bordeaux vineyard for the 2009-vintage: Comparison to 2006, 2007 and 2008 vintages. Food Chem. 126:1991-1999.

Mandelli, F., M.A. Berlato, J. Tonietto, B. Bergamaskhim. 2003. Phenology of wine grapes in the Seera Gaucha region. Pesqui. Agropecu. Gaúcha. 9:129-144.

Matheou, A., N. Stavropoulos and S. Samaras. 1995. Studies on table grape germplasm grown in Northern Greece. I. Maturity time, bunch characteristics and yield. Vitis. 34:155-138.

Mattivi, F., U. Vrhovsek, D. Masuero and D. Trainotti. 2009. Differences in the amount and structure of extractable skin and seed tannins amongst red grape varieties. Austr. J. Grape Wine Res. 15:27-35.

Menzel, A. 2005. A 500-year pheno-climatological view on the 2003 heatwave in Europe assessed by grape harvest dates. Meteorologische Zeitschrift. Meteorol. J. 14:7577.
Ortiz, J.M., J.P. Martín, J. Borrego, J. Chavez, I. Rodriguez, G. Munoz and F. Cabello. 2004. Molecular and morphological characterization of a Vitis gene bank for the establishment of a base collection. Genet. Res. Crop Ev. 51:403-409.

Poudel, P.R., R. Mochioka and Y. Fujita. 2010. Growth characteristics of shoots and roots of wild grapes native to Japan. J. ASEV Jpn. 21:8-12.

Rashid, K., and G. Rasul. 2011. Rainfall variability and maize production over the Potohar Plateau of Pakistan. Pak. J. Met. 8:63-74.

Sabir, A., S. Tangolar, S. Buyukalaca and S. Kafkas. 2009. Ampelographic and molecular diversity among grapevine (Vitis spp.) cultivars. Czech J. Genet. Plant Breed. 45:160-168.

Sajid, G.M. and Z. Ahmed. 2008. Evaluation of various levels of mineral nutrients and plant growth regulators for In vitro culture of grape. Pak. J. Bot. 40:329-336.

Sajid, G.M., M.K. Ilyas and R. Anwar. 2006. Effect of diverse hormonal regimes on in vitro growth of grape germplasm Pak. J. Bot. 38:385-391.

Saniya, J., I.S. Kanwar, N. Naruka and V.K. Meena. 2017. Heat unit requirement and phenological development of different grape varieties. IJCS. 5:1201-1204.

Santiago, J., S. Boso, P. Gago, V. Alonso-Villaverde and M. Martínez. 2007. Molecular and ampelographic characterisation of Vitis vinifera L." Albariño"," Savagnin Blanc" and" Caíño Blanco" shows that they are different cultivars. Span. J. Agric. Res. 5:333-340.

Schwartz, M.D. 2013. Phenology: An Integrative Environmental Science. Springer Netherlands, Dordrecht; p. 610.

Singh, I.A., U.V.M. Rao, D. Singh and R. Singh. 2007. Study on agrometeorological indices for soybean crop under different growing environment. J. Agrometeorol. 9:8185.

Ubalde, J.M., X. Sort, A. Zayas and R.M. Poch. 2010. Effects of Soil and Climatic Conditions on Grape Ripening and Wine Quality of Cabernet Sauvignon. J. Wine Res. 21:117.

Uddin, M., M. Shah, K.U. Rahman, R. Alam and M.A. Rauf. 2011. Evaluation of local and exotic grapes germplasm at Mingora, Swat. Sarhad J. Agric. 27:553-556.

Vafaee, Y., N. Ghaderi and A. Khadivi. 2017. Morphological variation and marker-fruit trait associations in a collection of grape (Vitis vinifera L.). Sci. Hortic. 225: 771-782.

Van Leeuwen, C., P. Friant, X. Chone, O. Tregoat, S. Koundouras and D. Dubourdieu. 2004. Influence of climate, soil and cultivar on terroir. Am. J. Enol. Vitic. 55:207-217. 